\title{
Coronary Angiographic Characteristics of Patients with First Myocardial Infarction Admitted in a Tertiary Care Cardiac Hospital in Bangladesh \\ M Kabiruzzaman ${ }^{1}$, MA Ali ${ }^{2}$, MN Islam ${ }^{3}$ \\ ${ }^{1}$ Department of Cardiology, National Heart Foundation Hospital \& RI. ${ }^{2}$ Department of Cardiology, NICVD. ${ }^{3}$ Department of Cardiology, BSMMU.
}

\section{Keywords: \\ First MI, \\ Coronary \\ angiogram.}

\begin{abstract}
-
Background: Coronary artery lesion characteristics of patients with First myocardial infarction (First MI) of Indian subcontinent origin in UK, is different from indigenous white population. The present study was aimed to observe coronary angiographic profile of first MI patients, hospitalized in a tertiary care hospital, in Bangladesh and to compare the results with published data of study done home and abroad.
\end{abstract}

Methods: This is a prospective observational study. A total of 100 cases of First MI patients were included in this study. Clinical history, physical examination, major risk factors, relevant investigations including ECG \& Echocardiogram and coronary angiogram of all patients were recorded.

Results: The coronary angiographic features of 100 patients revealed that $88 \%$ of the study population had significant coronary artery lesion (stenosis e"70\%). Normal coronary arteriogram was found in 5 patients (5\%); although they had myocardial infarction previously. Insignificant lesion (stenosis $<70 \%)$ was detected in 7 patients (7\%). Left anterior descending (LAD) arteries were affected in most of the patients (78\%), followed by right coronary artery (62\%) and left circumflex artery (55\%). Single vessel disease (33\%) and triple vessel diseases were equally prevalent among the study population.

Conclusion: Present study observed that triple vessel disease, diffuse pattern of lesions and combined type of lesions were more prevalent among the first MI patients. Increase in the number of risk factors was associated with progressive increase in severity of disease as defined by number of significant stenosis. Comparison of results of present study population with that of study done abroad shows that single vessel disease was more prevalent among European white patients who had first MI but triple vessel disease was more prevalent among our patients.

(Cardiovasc. j. 2010; 2(2) : 204-211)

\section{Introduction:}

Cardiovascular diseases are leading causes of morbidity and mortality in the industrialized countries, and they are also emerging as a prominent public health problem in the developing countries. ${ }^{1}$ The incidence of myocardial infarction seems to be higher in Bangladesh than the developed countries among the smokers. ${ }^{2} \mathrm{CAD}$ is more prevalent in western countries compared to our country but incidence of the disease is showing a downward trend in those countries. In our country, incidence of the disease is on the increase. ${ }^{3}$

Clinical characteristics of IHD in South Asian population have drawn attention in recent years.
High rates of coronary heart disease (CHD) in people of South Asian (Indian, Pakistani and Bangladeshi) origin were first reported from Singapore, South Africa and Trinidad in the 1950s; similar findings were recorded in the United Kingdom at the time of the 1971 census. ${ }^{4}$

There are studies done abroad on 'first myocardial infarction' in patients of Indian subcontinent and European origin. Hughes et al. studied first myocardial infarction because the changes in coronary anatomy were likely to be more easily defined in patients presenting with first myocardial infarction. ${ }^{5}$

Address of Correspondence: Dr Md Kabiruzzaman, Assistant Professor of Cardiology, National Heart Foundation Hospital \& Research Institute (NHFH \& RI), Dhaka, Bangladesh. 
Study performed by Shaukat et al. found that patients of first MI of Indian subcontinent origin had higher prevalence of diabetes; triple vessel disease was the commonest finding in patients of Indian subcontinent origin and single-vessel disease, the commonest in Europeans. They concluded that patients of Indian subcontinent origin are at substantially higher risk of mortality and of further coronary events than Europeans after first MI. This is probably due to their higher prevalence of diffuse coronary atheroma. Their need for investigation with a view to coronary revascularization is, therefore greater. ${ }^{6}$ Hughes et al concluded that atherogenesis arises earlier in Asians, contributing to premature first myocardial infarction. ${ }^{5}$

In this study, we aimed to assess the coronary angiographic characteristics of first MI patients and to compare the study results with that of done home and abroad.

\section{Materials and Methods:}

This prospective, observational study was carried out in the National Institute of Cardiovascular Diseases (NICVD), Dhaka, during the period July 1998 to October 1999. A total of 100 cases of first MI patients were selected for analysis from the patients admitted in different units of NICVD who underwent coronary angiogram (CAG). All the consecutive patients who had first MI and underwent coronary angiogram during the study period were considered as study population. First MI after PTCA/CABG, during procedure or operation, with concomitant congenital or valvular heart diseases was excluded from the study.

Diagnosis of First MI was done by attack of first time acute myocardial infarction with the presence of at least two of the following criteria: a) characteristic ischaemic chest pain; b) cardiac CKMB enzymes $>2$ times of normal upper limit; c) ECG changes lasting $>48$ hours.

Height, weight, age, sex, religion, clinical history, physical examination, major risk factors, relevant investigations including ECG \& Echocardiogram and coronary angiogram (CAG) of all patients were recorded.

The coronary angiographic criteria was followed according to Bogarty et $\mathrm{al}^{7} \&$ Cianflone et al. ${ }^{8}$
Severity-

a) Number of vessels- number of major epicardial vessels with e"70\% stenosis (maximum 3). Left main stenosis $\mathrm{e} " 50 \%=2$ vessels .

b) Stenosis longer than twice the normal diameter $=2$ stenosis. Maximum 3 stenosis per segment.

c) Occlusions- number of occlusion/subtotal occlusions (with delayed or incomplete antegrade flow).

Pattern-Discrete- $<3$ loci of diseases and all segment score $<3$. Diffuse- $\geq 3$ loci of diseases and/or $\geq$ segment score $=3$.

Types of lesions (Ambrose et $\left.\mathrm{al}^{9}\right)$ -

1) Concentric- symmetric narrowing of a coronary artery. The borders of this lesion were smooth or only slightly irregular.

2) Eccentric stenosis- asymmetric narrowing of a coronary artery.

3) Multiple irregularities- three or more serial and severe ( $\geq 50 \%)$ closely spaced obstructions in a coronary artery.

4) Combined type- when there was concomitant presence of more than one type of lesion in the CAG of same patient in any combination of lesion type.

CAG were performed by the expert cardiologists of NICVD using the standard Judkins procedure.

Smoking-: current smoker- now smoking $\geq 5$ sticks/ day.

Hypertension- blood pressure $140 / 90 \mathrm{mmHg}$ on 3 occasions or previously established hypertension.

Diabetes mellitus (DM): either prior established or at least 2 fasting plasma glucose $\geq 140 \mathrm{mg} / \mathrm{dl}$ (In AMI, at least 1 week after AMI).

Dyslipidemia: LDL- cholesterol $\geq 100 \mathrm{mg} / \mathrm{dl}$ or triglyceride $>150 \mathrm{mg} / \mathrm{dl}$ or both. Family history: any first degree relative having history of any type of established IHD. The study protocol was approved by the institutional ethical committee. Informed written consent was taken from each patient or his/her guardian.

Collected data were compiled and appropriate analysis were done using computerized software SPSS+. A p value $<0.05$ was taken as significant. 


\section{Results:}

The coronary angiographic features of 100 patients revealed that $88 \%$ of the study population had significant coronary artery lesion (stenosis $\geq 70 \%$ ). Normal coronary arteriogram was found in 5 patients (5\%); although they had myocardial infarction previously. Insignificant lesion (stenosis $<70 \%$ ) was detected in 7 patients (7\%). Left anterior descending (LAD) arteries were affected in most of the patients (78\%), followed by right coronary artery (62\%) and left circumflex artery (55\%). Majority of the lesions were distributed in the proximal segment of all major coronary arteries. Single vessel disease (33\%) and triple vessel diseases were equally prevalent among the study population (Table-I).

Table-I

Coronary angiographic profile of study population $(n=100)$

\begin{tabular}{|c|c|c|}
\hline Profile & er of patients & Percentage \\
\hline Normal coronaries & 5 & 5.0 \\
\hline Insignificant & 7 & 7.0 \\
\hline \multicolumn{3}{|c|}{ Dominancy of coronary arteries } \\
\hline Right dominance & 66 & 66.0 \\
\hline Left dominance & 34 & 34.0 \\
\hline Significant CAD present & t 88 & 88.0 \\
\hline SVD & 33 & 33.0 \\
\hline DVD & 22 & 22.0 \\
\hline TVD & 33 & 33.0 \\
\hline \multicolumn{3}{|c|}{ Location \&total no of lesion: } \\
\hline Left main & 6 & 6.0 \\
\hline LAD & 78 & 78.0 \\
\hline Proximal & 47 & 47.0 \\
\hline Middle & 28 & 28.0 \\
\hline Distal & 4 & 4.0 \\
\hline D1 & 12 & 12.0 \\
\hline D2 & 3 & 3.0 \\
\hline LCX & 55 & 55.0 \\
\hline Proximal & 29 & 29.0 \\
\hline Distal & 19 & 19.0 \\
\hline OM1 & 21 & 21.0 \\
\hline $\mathrm{OM} 2$ & 6 & 6.0 \\
\hline RCA & 62 & 62.0 \\
\hline Proximal & 35 & 35.0 \\
\hline Middle & 31 & 31.0 \\
\hline Distal & 6 & 6.0 \\
\hline PDA & 4 & 4.0 \\
\hline
\end{tabular}

Frequency of significant coronary artery lesion distribution (Table-II) demonstrates that most of the patients had more than one lesion (65\%). Among these two lesions per patients were more prevalent (24\%) followed by 1 lesion $(23 \%),>4$ lesions (17\%), 3 lesions (15\%), 4 lesions (9\%) in the study population. Total occlusion of the coronary arteries was present in 32 patients (32\%). Among these single occlusion was more prevalent $(27 \%)$, followed by double occlusion (5\%). None of the patient had more than two total occlusions.

\section{Table-II}

Frequency of lesion in the study population $(n=100)$

\begin{tabular}{lcc}
\hline $\begin{array}{l}\text { Number of } \\
\text { lesions (Per }\end{array}$ & Number of patients & Percentage \\
patient) & & \\
\hline No lesion & 5 & 5.0 \\
Insignificant lesion & 7 & 7.0 \\
(<50\% stenosis) & & \\
Significant lesion present: & \\
$\quad 1$ lesion & 23 & 23.0 \\
$\quad 2$ lesions & 24 & 24.0 \\
$\quad 3$ lesions & 15 & 15.0 \\
$\quad 4$ lesions & 9 & 9.0 \\
$\quad>4$ lesions & 17 & 17.0 \\
Total occlusion: & & \\
1 occlusion & 27 & 27.0 \\
$\quad 2$ occlusion & 5 & 5.0 \\
$>2$ occlusion & 0 & 0.0 \\
\hline
\end{tabular}

Distribution of the type of significant lesion (Table-III) demonstrate that total number of lesions were 278 among the study population $(\mathrm{n}=88)$. Combined type lesions $(50 \%)$ were found most prevalent, followed in decreasing frequency, concentric type (22\%), total occlusion (9\%), multiple irregularity (4\%), and eccentric type (3\%). Among the combined type lesion, the combination of concentric and multiple irregularity type of lesions were found most common (17\%), followed by combination lesion of concentric type with total occlusion (10\%). 
Table-III

Distribution of type of significant lesion in the study population $(n=100)$

\begin{tabular}{lccc}
\hline $\begin{array}{l}\text { Type of } \\
\text { lesion }\end{array}$ & $\begin{array}{c}\text { Number } \\
\text { of lesions }\end{array}$ & $\begin{array}{c}\text { Number } \\
\text { of patients }\end{array}$ & Percentage \\
\hline Concentric & 51 & 22 & 22.0 \\
Eccentric & 8 & 3 & 3.0 \\
Multiple irregularity & 10 & 4 & 4.0 \\
Total occlusion & 14 & 9 & 9.0 \\
Combined & 195 & 50 & 50.0 \\
\hline Total & 278 & 88 & 88.0
\end{tabular}

Positive correlation was found between the numbers of significant lesions with frequency of risk factors (Table-IV). Patients without risk factor had lesion 1-2 (mean 1.10 \pm 0.08 ) and with risk factors lesion ranges $1-4$ (mean $2.30 \pm 0.96$ ), i.e. the mean severity increases proportionately with the number of risk factors $(\mathrm{r}=+0.98 ; \mathrm{P}<0.01)$.
Table-IV

Correlation of number of significant lesion by frequency of risk factors $(n=88)$

\begin{tabular}{lccc}
\hline $\begin{array}{l}\text { Frequency of } \\
\text { risk factors }\end{array}$ & $\begin{array}{c}\text { Number of lesion } \\
\text { per patient }\end{array}$ & $\begin{array}{c}\text { Range } \\
\text { Mean } \pm \mathrm{SD}\end{array}$ & P value \\
\hline $0(\mathrm{n}=4)$ & $1-2$ & $1.10 \pm 0.08$ & \\
$1(\mathrm{n}=21)$ & $1-3$ & $1.71 \pm 0.62$ & \\
$2-3(\mathrm{n}=58)$ & $1-4$ & $1.92 \pm 0.88$ & $\mathrm{r}=+0.98$ \\
$\mathrm{e} "(\mathrm{n}=17)$ & $1-4$ & $2.30 \pm 0.96$ & $\mathrm{p}=<0.01$ \\
\hline
\end{tabular}

Multiple coronary arteries were significantly affected among the study population with age range of 40-60 years (Table-V). Most of them were male 53 (55\%), Muslim 53 (56\%) and residence in urban area $47(59 \%)$.

Significant lesions in multiple coronary arteries were found more prevalent in 34 patients $(62 \%)$ with height ranges from $160-169 \mathrm{~cm}$, weight ranges from $65-75 \mathrm{~kg}$ in $24(62 \%)$ and body mass index $<25$ $\mathrm{kg} / \mathrm{m}^{2}$ in 35 patients $(54 \%)$ (Table-V).

Table-V

Clinical and angiographic profile by demographic characteristics $(n=100)$

\begin{tabular}{|c|c|c|c|c|c|c|}
\hline \multirow[t]{2}{*}{$\overline{\text { Variables }}$} & \multicolumn{2}{|c|}{ MI location } & \multicolumn{2}{|c|}{ Risk factor } & \multicolumn{2}{|c|}{ CAG profile } \\
\hline & Anterior & Inferior & Single & Multiple & SVD & MVD \\
\hline \multicolumn{7}{|l|}{$\overline{\text { Age }}$} \\
\hline$<40(\mathrm{n}=13)$ & $7(54)$ & $6(46)$ & $5(38)$ & $5(38)$ & $5(38)$ & $7(54)$ \\
\hline $40-60(\mathrm{n}=69)$ & $43(62)$ & $26(38)$ & $12(18)$ & $56(81)$ & $24(35)$ & $41(59)$ \\
\hline$>60(\mathrm{n}=18)$ & $8(45)$ & $10(55)$ & $4(22)$ & $14(78)$ & $4(22)$ & 7(39) \\
\hline \multicolumn{7}{|l|}{ Sex } \\
\hline Male $(\mathrm{n}=96)$ & $57(59)$ & $39(41)$ & $19(20)$ & $73(76)$ & $31(32)$ & $53(55)$ \\
\hline Female $(\mathrm{n}=4)$ & $1(25)$ & $3(75)$ & $2(50)$ & $2(50)$ & $2(50)$ & $2(50)$ \\
\hline \multicolumn{7}{|l|}{ Residence (\%) } \\
\hline Rural $(\mathrm{n}=21)$ & $12(57)$ & $9(43)$ & $6(29)$ & $11(52)$ & $5(24)$ & $8(38)$ \\
\hline $\operatorname{Urban}(\mathrm{n}=79)$ & $46(58)$ & $33(42)$ & $15(19)$ & $64(81)$ & $28(35)$ & $47(59)$ \\
\hline \multicolumn{7}{|l|}{ Height (cm\%) } \\
\hline$\leq 159(\mathrm{n}=29)$ & $14(48)$ & $15(52)$ & $6(21)$ & $19(65)$ & $13(45)$ & $11(38)$ \\
\hline $160-169(\mathrm{n}=5)$ & $33(60)$ & $22(40)$ & $12(22)$ & $43(78)$ & $15(27)$ & $34(62)$ \\
\hline$\geq 170(\mathrm{n}=16)$ & $11(69)$ & $5(31)$ & $3(19)$ & $13(81)$ & $5(31)$ & $10(62)$ \\
\hline \multicolumn{7}{|l|}{ Weight $(\mathrm{kg} \%)$} \\
\hline$\leq 55(\mathrm{n}=17)$ & $8(47)$ & $9(53)$ & $5(29)$ & $9(53)$ & $7(41)$ & $9(53)$ \\
\hline $55-64(\mathrm{n}=34)$ & $22(65)$ & $12(35)$ & $5(15)$ & $28(82)$ & $12(35)$ & $16(47)$ \\
\hline $65-74(\mathrm{n}=39)$ & $19(49)$ & $20(51)$ & $8(21)$ & $31(79)$ & $10(26)$ & $24(62)$ \\
\hline$\geq 75(\mathrm{n}=10)$ & $9(90)$ & $1(10)$ & $3(30)$ & $7(70)$ & $4(40)$ & $6(60)$ \\
\hline \multicolumn{7}{|l|}{$\mathrm{BMI}\left(\mathrm{kg} / \mathrm{m}^{2}\right)$} \\
\hline$<25(\mathrm{n}=65)$ & $39(60)$ & $26(40)$ & $8(12)$ & $57(88)$ & $19(29)$ & $35(54)$ \\
\hline$\geq 25(\mathrm{n}=35)$ & $19(54)$ & $16(46)$ & $13(37)$ & $18(51)$ & $14(40)$ & $20(57)$ \\
\hline
\end{tabular}




\section{Table-VI}

Clinical and angiographic profile by risk factors $(n=96)$

\begin{tabular}{|c|c|c|c|c|c|c|}
\hline Variables & Hypertensive & Diabetic & Smoker & Dyslipidaemia & Family history & $>1$ Risk factor \\
\hline \multicolumn{7}{|l|}{ Age (Years) } \\
\hline$<40(\mathrm{n}=13)$ & 1 & 2 & 1 & 1 & 0 & 5 \\
\hline $40-60(\mathrm{n}=69)$ & 4 & 3 & 2 & 2 & 1 & 56 \\
\hline$>60(\mathrm{n}=18)$ & 1 & 1 & 1 & 1 & 0 & 14 \\
\hline \multicolumn{7}{|l|}{ Sex } \\
\hline Male $(\mathrm{n}=96)$ & 3 & 3 & 11 & 2 & 0 & 73 \\
\hline Female $(\mathrm{n}=4)$ & 1 & 0 & 0 & 1 & 0 & 2 \\
\hline Residence & 2 & 2 & 2 & 0 & 0 & 11 \\
\hline $\operatorname{Rural}(\mathrm{n}=21)$ & 4 & 5 & 4 & 2 & 0 & 64 \\
\hline \multicolumn{7}{|l|}{ Urban $(\mathrm{n}=79)$} \\
\hline \multicolumn{7}{|l|}{$\mathrm{BMI}\left(\mathrm{kg} / \mathrm{m}^{2}\right)$} \\
\hline$<25(\mathrm{n}=65)$ & 2 & 2 & 3 & 1 & 0 & 57 \\
\hline$>25(\mathrm{n}=35)$ & 3 & 3 & 2 & 4 & 1 & 18 \\
\hline \multicolumn{7}{|c|}{ Number of diseased vessel } \\
\hline $\operatorname{SVD}(\mathrm{n}=33)$ & 5 & 7 & 8 & 3 & 4 & 6 \\
\hline $\operatorname{DVD}(\mathrm{n}=22)$ & 2 & 2 & 2 & 1 & 1 & 14 \\
\hline TVD $(\mathrm{n}=33)$ & 3 & 2 & 1 & 3 & 2 & 22 \\
\hline
\end{tabular}

\section{Table-VII}

Comparison of clinical characteristics and coronary angiography in patients of the present study and of European origin in the UK( Shaukat et al. 1997) $)^{6,16}$

\begin{tabular}{lccc}
\hline Variables & $\begin{array}{c}\text { Present } \\
\text { study }\end{array}$ & $\begin{array}{c}\text { European } \\
\text { origin }\end{array}$ & P value \\
\hline Mean age (Years) & 49.3 & 57.6 & $<0.05$ \\
Smoker (\%) & 80.0 & 63.0 & $<0.01$ \\
Known hypertension (\%) & 46.0 & 15.0 & $<0.01$ \\
Known diabetes (\%) & 34.0 & 9.0 & $<0.001$ \\
CAG: & & & $<0.05$ \\
$\quad$ SVD & 33.0 & 41.0 & $<0.05$ \\
$\quad$ DVD & 22.0 & 35.0 & $<0.01$ \\
$\quad$ TVD & 33.0 & 21.0 & \\
\hline
\end{tabular}

Table-VIII

Comparison of risk factors for coronary artery disease among Asian and white patients who lives in Birmingham (Lowry et al. 1984) ${ }^{17}$ and the present study population of Bangladesh

\begin{tabular}{lcccc}
\hline $\begin{array}{l}\text { Risk factors } \\
(\%)\end{array}$ & $\begin{array}{c}\text { Asian } \\
\text { (a) }\end{array}$ & $\begin{array}{c}\text { White } \\
\text { (b) }\end{array}$ & $\begin{array}{c}\text { Present } \\
\text { Study } \\
\text { (c) }\end{array}$ & $\begin{array}{c}\text { P value } \\
\text { (vs present study) } \\
\text { (a vs c / b vs c) }\end{array}$ \\
\hline Smoking & 67.0 & 91.0 & 80.0 & $<0.05 / \mathrm{NS}$ \\
Hypertension & 15.0 & 12.0 & 46.0 & $<0.001 /<0.01$ \\
Diabetes & 9.0 & 4.0 & 34.0 & $<0.01 /<0.001$ \\
Weight $(\mathrm{kg})$ & 70.0 & 76.5 & 63.88 & $\mathrm{NS} / \mathrm{NS}$ \\
(Mean $\pm \mathrm{SD})$ & \pm 9.9 & \pm 10.4 & \pm 8.22 & \\
BMI $(\mathrm{kg}=\mathrm{m} 2)$ & 24.3 & 25.8 & 24.23 & $\mathrm{NS} / \mathrm{NS}$ \\
(Mean $\pm \mathrm{SD})$ & \pm 3.0 & \pm 3.0 & \pm 2.60 & \\
\hline
\end{tabular}


Table-IX

Comparison of mean values of risk factors for cardiovascular diseases in Mexican-Americans (MA) and non-Hispanic whites (NHW) (Mitchell et al. 1991) ${ }^{18}$ and the present study (PS) population of Bangladesh

\begin{tabular}{lcccc}
\hline Risk factors & $\begin{array}{c}\text { MA } \\
\text { (a) }\end{array}$ & $\begin{array}{c}\text { NHW } \\
\text { (b) }\end{array}$ & $\begin{array}{c}\text { Present } \\
\text { Study } \\
\text { (c) }\end{array}$ & $\begin{array}{c}\text { P value (vs } \\
\text { present study) } \\
\text { (a vs c / b vs c) }\end{array}$ \\
\hline $\begin{array}{l}\text { Age (Years) } \\
\text { Body mass index } \\
\left(\mathrm{kg} / \mathrm{m}^{2}\right)\end{array}$ & 43.0 & 44.8 & 49.30 & $\mathrm{NS} / \mathrm{NS}$ \\
$\begin{array}{l}\text { Total cholesterol } \\
(\mathrm{mg} / 100 \mathrm{ml})\end{array}$ & 28.0 & 27.3 & 24.23 & $\mathrm{NS} / \mathrm{NS}$ \\
$\begin{array}{l}\text { HDL- cholesterol } \\
(\mathrm{mg} / 100 \mathrm{ml})\end{array}$ & 207.1 & 205.6 & 217.79 & $\mathrm{NS} / \mathrm{NS}$ \\
$\begin{array}{l}\text { Triglycerides } \\
(\mathrm{mg} / 100 \mathrm{ml})\end{array}$ & 42.7 & 43.2 & 33.39 & $<0.05 /<0.05$ \\
$\begin{array}{l}\text { Diabetes }(\%) \\
\text { Smoking }(\%)\end{array}$ & 149.0 & 137.3 & 213.47 & $<0.05 /<0.01$ \\
\hline
\end{tabular}

Table-X

ECG location of myocardial infarction $(n=100)$

\begin{tabular}{lcc}
\hline Location & Number of patients & Percentage \\
\hline Inferior & 42 & 42.0 \\
Anterior & 58 & 58.0 \\
Anteroseptal & 30 & 30.0 \\
Anterolateral & 22 & 22.0 \\
Extensive-anterior & 6 & 6.0 \\
\hline
\end{tabular}

Table-XI

Left ventricular ejection fraction (EF) of the study population by two- dimensional echocardiography (Simpsons's method) $(n=100)$

\begin{tabular}{lcc}
\hline EF \% & Number of patients & Percentage \\
\hline$\geq 50$ & 67 & 67.0 \\
$40-49$ & 30 & 30.0 \\
$30-39$ & 3 & 3.0 \\
\hline
\end{tabular}

\section{Discussion:}

The CAG of total 100 patients with first MI reveals five $(5 \%)$ patients had normal coronary arteries, although they had an acute myocardial infarction previously and insignificant lesion in $7 \%$ patients. Amanullah et al found similar results in one patient and focal lesion in two patients. They concluded that smoking can cause focal lesion in coronary artery and the lesion is reversible if the patient gave up smoking. They proposed that these lesions are thrombogenic rather than atherogenic. ${ }^{10}$ Rahman et al. found $10.62 \%$ CAG were normal and $5.63 \%$ patients had insignificant coronary artery disease in all subsets of IHD patients. ${ }^{11}$ Safiuddin et al. found normal coronary artery and insignificant lesion in $12 \%$ patients of unheralded acute myocardial infarction. ${ }^{12}$ Similar result was observed in the present study.

In the present study, single vessel disease (SVD) (33\%) and triple vessel disease (TVD) (33\%) were equally prevalent. Double vessel disease (DVD) was found in $22 \%$ patients (Table-I). Safiuddin et al. found SVD in 54\%, DVD in 22\% and TVD in 12\% patients with unheralded acute myocardial infarction of 50 cases. ${ }^{12}$ This difference could be due to selection criteria. Akanda et al. observed TVD (42\%) were more prevalent in their study, followed by DVD (33\%) and SVD (25\%) in all subsets of IHD patients. ${ }^{13}$ The increased prevalence of TVD could be due to inclusion of chronic stable angina. Rahman et al. found DVD (39\%) more prevalent in their study, followed by SVD (35\%) and TVD (11\%). ${ }^{11}$ The difference with the present study was probably due to selection criteria. They included all subsets of IHD patients and stenosis of coronary vessel $>80 \%$ were accepted as severe lesion.

An average of 2.78 lesions resulting in at least $50 \%$ luminal narrowing of major arteries was found per 
patient. Akanda et al. found it as 2.16 lesions per patient and Safiuddin et al. observed it as 3.10 lesions per patient. ${ }^{13,12}$

The left anterior descending artery was most frequently involved (78\%), followed by right coronary artery (62\%), circumflex (55\%) and left main coronary artery (6\%). Proximal involvement of all major coronary arteries was observed more prevalent among the study group. Akanda et al. found similar results in their study. ${ }^{13}$ Although Safiuddin et al. observed similar chronological involvement of coronary arteries, but their prevalence was lower (LAD- 64\%, RCA- 38\%, and LCX- $32 \%){ }^{12}$

These differences are in addition to the above mentioned patient selection criteria, probably due to a marked difference in the cut-off point of stenosis.

The present study revealed that diffuse pattern of lesions (56\%) was more prevalent than the discrete pattern (39\%). Regarding types of lesion, combined type (50\%) was found more prevalent, followed by concentric type (22\%). Comparable data is not available in our country.

The severity of CAG lesion correlate positively with frequency of risk factors (Table-IV). There were significant difference among patients with single risk factor and multiple risk factors. This finding is similar to that of Akanda et al. in Bangladesh. ${ }^{13}$ Kannel et al. and Fried et al. showed similar results. ${ }^{14,15}$

Angiographic profile of the present study by demographic characteristics showed that multiple vessel disease was more prevalent in age group $40-60$ years $(59 \%)$, male (55\%), urban people $(59 \%)$, height $160-169 \mathrm{~cm}(62 \%)$, weight $65-74 \mathrm{~kg}(62 \%)$, BMI $<25 \mathrm{~kg} / \mathrm{m}^{2}$ (54\%) (Table-V). Comparable data is not found in Bangladeshi patients.

Comparison of clinical characteristics and coronary angiogram (Table- VII) between the patients of present study and that of European origin (done by Shaukat et al. 1997) revealed that there was significant difference in mean age at onset of the disease, prevalence of risk factors and coronary artery disease. The mean age (49.30 vs 57.6 ; $\mathrm{P}<0.05)$ at infarction was less in the present study than that in European patients. Prevalence of smoking $(80 \%$ vs $63 \%$; $p<0.01)$ and diabetes $(34 \%$ vs $9 \% ; \mathrm{P}<0.001$ ) were found significantly higher in present study population than that in European white patients. ${ }^{6}$

The present study observed some striking differences in disease severity with that of European white patients (who live in Northern Europe). The extent of coronary atheroma was significantly greater in the present study. Present population had significantly higher prevalence of triple ( $33 \%$ vs $21 \%, \mathrm{p}<0.01)$, but less prevalence of single- $(33 \%$ vs $41 \%, \mathrm{p}<0.05)$ and double-vessel disease $(22 \%$ vs $35 \%, \mathrm{p}<0.05)$ than the white (TableVII). ${ }^{16}$

Comparison of risk factors with other published data done abroad are shown in Table-VIII \& IX. ${ }^{17,18}$

Risk factor frequencies were significantly correlated with number of significant coronary artery lesion present per patient. The more the risk factors, the more the number of significant lesion (Table-IV, VI). Grundtvig et al concluded that First AMI occur significantly more prematurely in women smoker than in men smokers implying that twice as many years were lost by women as by men smokers. ${ }^{19}$

Highest percent of study patients had chest pain quality of squeezing (40\%) in nature, retrosternal location $(88 \%)$ with radiation toward medial aspect of left arm (70\%).

Determination of site of infarction by electrocardiography reveals majority of the patients were of anterior myocardial infarction (58\%) (Table-X). Echocardiographic estimation of ejection fraction $\geq 50 \%$ found in most of the patients (Table- XI).

\section{Conclusion:}

Present study observed that triple vessel disease, diffuse pattern of lesions and combined type of lesions were more prevalent among the first MI patients. There is steady and progressive increase in the number of risk factors which is associated with progressive increase in severity of disease as defined by number of significant stenosis. Comparison of results of present study population with that of the study done abroad shows that single vessel disease is more prevalent among European; white patients but triple vessel disease is more prevalent among present study population. 
As the study was done in highly selected group of patients, comprising small cohorts in one hospital only, the study may not reflect the true picture of Bangladeshi patients. But this study will definitely serve as a soil for similar further work in this field.

\section{References:}

1. Malik A, Islam MN, Zafar A, et al. Clinical patterns of ischaemic heart diseases and its association with some known risk factors. Bangladesh Heart $J$ 1987; 2:1-9.

2. Jalaluddin M, Malik A. A study of relation of Smoking with myocardial infarction in 100 cases. Bangladesh Heart $J$ 1986; 1:32-5.

3. Sirajul Hoque KMHS. Status of cardiovascular services in Bangladesh. Heart Res Ins Bull 1993; 21-4.

4. McKeigue PM. Coronary heart disease in Indians, Pakistanis and Bangladeshis: Aetiology and possibilities for prevention [editorial]. Br Heart J 1992; 67: 341-2.

5. Hughes LO, Raval U, Raftery EB. First myocardial infarction in Asian and white men. Br Med J 1989; 298: 1345-50.

6. Shaukat N, Lear J, Lowy A, et al. First myocardial infarction in patients of Indian subcontinent and European origin: Comparison of risk factors, management and long-term outcome. $\mathrm{Br} \mathrm{Med} J$ 1997; 314:639-42.

7. Bogaty P, Brecker SJ, White SE, et al. Comparison of coronary angiographic findings in acute and chronic first presentation of ischaemic heart disease. Circulation 1993; 87: 1938-46.

8. Cianflone D, Ciccirillo F, Buffon A, et al. Comparison of coronary angiographic narrowing in stable angina pectoris, unstable angina pectoris and in acute myocardial infarction. Am J Cardiol 1995; 76: 215-9.

9. Ambrose JA, Winters SL, Stern A, et al. Angiographic morphology and the pathogenesis of unstable angina pectoris. J Am Coll Cardiol 1985; 5: 609- 16.
10. Amanullah M, Thapa LB, Farooque GM, et al. A profile of 51 cases of acute myocardial infarction amongst young Bangladeshi. In: Proceedings of Bangladesh-Japan Joint Conference on Cardiovascular Disease, Dhaka 1984; JICA, 118-21.

11. Rahman H, Hossain A, Miah AY, et al. Coronary artery disease: Angiographic study of 160 cases. Bangladesh $J$ Radiol Imag 1995; 3: 5-8.

12. Safiuddin M, Rahman S, Sadequzzaman M, et al. Coronary angiographic profile of unheralded acute myocardial infarction: A study of 50 cases in NICVD, Dhaka. Chest Heart J 1998; 22: 49-52.

13. Akanda MAK, Rahman S, Chowdhury AHK, et al. Arteriographic pattern in coronary heart disease in Bangladesh demonstrated by selected coronary angiogram. Bangladesh Heart $J$ 1996; 11: 55-9.

14. Kannel WB, McGee D, Gordon TA. General cardiovascular risk profile: The Framingham study. Am J Cardiol 1976; 38: 46-51.

15. Fried LP, Pearson TA. The association of risk factors with arteriographically defined coronary artery disease. Am J Epidemiol 1987; 125: 453-88.

16. Shaukat N, de Bono DP, Cruck shank JK. Clinical features, risk factors and referral delay in British patients of Indian subcontinent and European origin with angina matched for age and extent of coronary atheroma. Br Med J 1997; 307: 717-8.

17. Lowry PJ, Glover DR, Mace PJE, et al. Coronary artery disease in Asian in Birmingham. Br Heart J 1984; 52: 610-3.

18. Mitchell BD, Hazuda HP, Haffner SM, et al. Myocardial infarction in Mexican-Americans and non-Hispanic whites: the San Antonio Heart Study. Circulation 1991; 83: $45-51$

19. Grundtvig M, Hagen TP, German M, Reikvam A. Sexbased differences in premature first myocardial infarction caused by smoking: twice as many years lost by women as by men. Eur $J$ Cardiovasc Prev Rehabil 2009 Apr; 16(2): 174-9. 